\title{
PREVAILING TENDENCIES IN LOCAL SELF-GOVERNANCE: SCOPE OF LOCAL PUBLIC AFFAIRS AND TERRITORIAL TRENDS IN EUROPE
}

\author{
Judit Siket \\ University of Szeged, Faculty of Law and Political Sciences
}

\begin{abstract}
Focusing on the content of local autonomy, congruent trends could be identified in European countries. Fundamental values of local self-governance prevailing in Europe are included in the European Charter of Local Self-Government. Having regard to the constitutional principle of separation of powers, Charter takes into consideration local self-governments as part of the executive power. Even though the basic principles specify the political and institutional framework of territorial and local administration, the intergovernmental relations also show changing nature. The public administration systems of the Member States of the European Union do not fall within the scope of the EU law, nevertheless, should be analyzed to what extent these processes are influenced by Europeanization progress and what other factors may occur. Remarkable territorial and competence-theory changes were implemented in some States recently, like the Big Society concept in the United Kingdom and the territorial reforms in France.
\end{abstract}

Key words: local governance, territorial reforms, the scope of local public affairs

\section{INTRODUCTION}

After World War II some typical trends, a kind of harmonization could be observed in the local selfgovernance. Research has shown that at least two main sources can be distinguished, on one hand the activity of Council of Europe and on the other hand the implementation of EU policies. The European Charter of Local Self-Government (hereinafter: Charter) serves as a framework for the analysis, nevertheless, the implementation of EU policies, especially the regional policy cannot be ignored either. Having regard to the constitutional principle of separation of powers, Charter takes into consideration local self-governments as part of the executive power. The current paper attempts to review the general European values in the field of local self-governance, and to introduce the key elements of European local self-government models. Even though the basic principles specify the political and institutional framework of territorial and local administration, the intergovernmental relations also show changing nature. Recently, remarkable territorial and competence-theory changes were implemented in some States, like the Big Society concept in the United Kingdom and the territorial reforms in France.

The study attempts to give a comprehensive overview of prevailing tendencies in local self-governance, especially in the constitutional and legal status of local self-government, and in the scope of local public affairs. The paper could be divided into three main sections, the first part aims to 
illustrate the decentralization processes in Europe after World War II, and the Europeanization of local self-government; the second unit examines the content of right to self-governance and modelling of local self-governance. The third section refers to the significant reform steps that are taking place in some European countries, such as territorial and theoretical changes in the United Kingdom and in France.

\section{DECENTRALIZATION AND EUROPANIZATION IN THE FIELD OF LOCAL SELF-GOVERNANCE}

\subsection{Decentralization from theoretical aspect and decentralization trends in Europe}

Decentralization is a key element of the governance in a modern democratic state, as an important state organizational principle. Two main methods of decentralization are well-known, on one hand the territorial decentralization and on the other hand the functional decentralization. The paper only covers the former form; the functional decentralization as transfer of public administration powers to non-public administration bodies is not the subject of this paper. There are three dimensions of the territorial decentralization: political, administrative and fiscal decentralization. The political decentralization means generally the transfer of decision-making powers and financial resources to local self-government units. The administrative decentralization implies that the local administration gets major, decisive role in local public affairs. The financial decentralization (known as fiscal federalism) is resulting in the transfer of financial resources for regional or local level government bodies that have decision-making power, ensuring efficient and transparent use of these resources.

The concept of decentralization should be distinguished from the concept of devolution. The devolution entails transferring of decision-making authority, whereby the empowered state unit has decision-making power in the field of public affairs. The United Kingdom is an example for the operation of compound state where England, Northern Ireland, Scotland, Wales as independent states have devolved powers, however, not being classified as a federal state. ${ }^{1}$

Decentralization could be identified as the feature of local self-governance. Ilona Pálné Kovács considered decentralization as the measure of democracy. ${ }^{2}$ The legal approach to the decentralization was developed also by Hans Kelsen: 'The definition of self-governance includes the incorporated theory of decentralization and democracy, and autonomy... Fighting for self-government can be regarded just as the struggle for democracy ${ }^{3}$ Edward C. Page interpreted the theory of decentralization on the political and legal basis following the thesis of $\mathrm{H}$. Kelsen. Page examined options that are available for the local political elite to shape public services in political and legal aspects in seven nation states in Europe (France, Britain, Italy, Spain, Norway, Denmark and Sweden). ${ }^{4}$ Fuhi-

1 See for further details: Wagana, D. M. - Iravo, M. A. - Nzulwa, J. D.: Analysis of the Relationship Between Devolved Governance, Political Decentralization, and Service Delivery: A Critical Review of Literature. In: European Scientific Journal, vol. 11, November 2015, No. 31, p. 457-472.

2 PÁLNÉ, K. I.: A helyi-területi önkormányzati rendszerek. In: Összehasonlító alkotmányjog (szerk. Tóth Judit - Legény Krisztián). Budapest: Complex Kiadó, 2006, p. 282.

3 Kelsen, H.: Az államélet alapvonalai. Prudentia Iuris 7. Miskolc, 1997, Art. 45, par. 70-71.

4 Page, E. C.: Localism and Centralism in Europe. The Political and Legal Bases of Local Self-Government. Oxford: Oxford University Press, 1991, p. 6. 
miko Saito, examining the characteristics of democratic decentralization, considered decentralization desirable, especially since the municipalities are able to recognize the needs of the population in the area of public services better. ${ }^{5}$ The principle of subsidiarity also appears in this interpretation.

The completion of 'devolution revolution " has been shown by Merilee S. Grindle as a transfer of financial, political, administrative, public service powers which resulted in a radical structural change in the public responsibility and in the field of sharing of autonomy. The new formations of international governance - which are inherent to globalization and decentralization - also help to redefine the role of central government. ${ }^{6}$

In the 1950s and 1960s a strong decentralization process was typical in the Western European States. This process resulted in reorganization of the public tasks of local government in a number of states. Requirement of effectiveness was one of the root causes.

Prevailing local government reforms can be identified in two main streams. On one hand the so called traditional reform steps, and on the other hand the impact of the New Public Management reforms. Traditional reforms aimed primarily at strengthening the political and administrative institution system in the welfare states of the 1960s. The New Public Management reform steps in the 1970s focused on reduction of the role of state, correcting the deficiencies of the welfare state and public administration. Parallel to the welfare state concept expansion, the significance and role of municipal autonomy diminished. However, in the 1970s there were cracks in the foundations of the welfare state. In contrast, the neo-liberalist ideological, political and economic system became dominant. The influence of neo-liberalism can be traced in the state decentralization process. The NPM movement therefore constituted a kind of internal modernization efforts. It can be considered an effect of neo-liberal economics in the field of public administration. The primary objective to increase the efficiency of the redistribution determined public tasks. Regarding the public administration political and administrative reforms (NPM), privatization and deregulation have served as a tool to create market conditions. The penetration of neo-liberalism increased the importance of the public choice for the citizens.

The demand of decentralization, in form of concept of 'Power to the people' heavily logged in the 1970s and 1980s in America and in the late 1980s and early 1990s in Central and Eastern European countries. This effort soon caused that the local policy and accountability have been raised to the level of democratically elected local government. The requirement of decentralization apparently started from the premise that local governments are better able to learn about the needs of the people and act accordingly, since it is much closer to the population than the central government.

After the collapse of soviet-type regime, the most important issue under discussion was the optimal size of local governments. After the financial crisis of 2008/2009 and the following economic recession, local governments in European countries were seriously affected by the consequences of the economic downturn. There were numerous attempts to improve service delivery through rationalization, cooperation of private and public entities. Energy efficiency programs were launched, local economic development programs were implemented. ${ }^{?}$

5 Saito, F. (ed.): Foundations for Local Governance. Decentralization in ComparativePerspective. Heidelberg: PhysicaVerlag, 2008, p. 2-4.

6 GRINDLE, M. S.: Going Local. Decentralization, Democratization, and the Promise of Good Governance. Princeton and Oxford: Princeton University Press, 2007, p. 4.

7 PÉTERI, G.: Decentralization in Eastern Europe: Grab the Moment!, p. 47. Available at: http://www.kozjavak.hu/en/ decentralization-eastern-europe-grab-moment 


\subsection{Decentralization in the practice of international institutions}

The importance of local democracy and local autonomy can be seen in the development of localism. The issue of decentralization has high priority within the United Nations Development Organization's policy. It is worth emphasizing that a number of definitions of decentralization is determined in the United Nations Development Program (UNDP). What is common is that the democratic decentralization is essentially linked to the exercise of local public power. ${ }^{8}$

Jesse C. Ribot admitted the following demand: 'Decentralization requires both power transfers and accountable representation. ... Decentralization is not about the downsizing or dismantling of central government; rather, it calls for mutually supportive democratic central and local governance."

The United Cities and Local Governments (UCLG) in close cooperation with the United Nations plays an important role in protecting the interests of local governments. ${ }^{10}$ The nature of decentralization was defined as follows in a report of 2008: 'The local self-government is a component of decentralization. [...] It presumes the free exercise of power and establishing organizations within the framework of law; the extent of freedom could prevail widely in different fields, but the idea itself is not affected.' ${ }^{\prime 1}$

Finally, the International Association of Local Authorities (IULA) adopted a Declaration in 1993, the essential elements and the principles of local governance being summarized as follows. 'Article 2: Concept of local self-government 1. Local self-government denotes the right and the duty of local authorities to regulate and manage public affairs under their own responsibility and in the interests of the local population. 2. This right shall be exercised by individuals and representative bodies freely elected on a periodical basis by equal, universal suffrage, and their chief executives shall be so elected or shall be appointed with the participation of the elected body.' ${ }^{12}$

\subsection{The principle of subsidiarity}

Parallel to the application of the decentralization - being related to the state organizational principles - it is necessary to examine the interpretation possibilities of subsidiarity principle. It means generally that decisions should be taken at the closest level to the citizen, in compliance to requirements of efficiency. The United Nations Centre for Human Settlements gave the following definition of the principle of subsidiarity: 'The principle of subsidiarity constitutes the rationale underlying to the process of decentralization. According to that principle, public responsibilities should be exercised by those elected authorities, which are closest to the citizens. ${ }^{13}$ In April 2007 the Governing Council issued a guideline for further development of the European Charter of Local Self-

8 See for further details: Decentralization: A Sampling of Definitions (Working paper prepared in connection with the Joint UNDP-Government of Germany evaluation of the UNDP role in decentralization and local governance) October 1999. Available at: http://web.undp.org/evaluation/evaluations/documents/decentralization_working_report.PDF

9 RIBOT, J. C.: Democratic Decentralization of Natural Resources: Institutionalizing Popular Participation.. Washington DC: World Resources Institute, 2002, p. 1-2. Available at: http://pdf.wri.org/ddnr_full_revised.pdf 1-2.

10 KOVÁCS, L.: Helyi önkormányzatok hálózatainak szerepe a globális kormányzásban. In: Tér és Társadalom, 24. évf. 2010/1, p. 106-107.

11 United Cities and Local Governments (UCLG). Decentralisation and local democracy in the world. First UCLG World Report. Barcelona: UCLG, 2008.

12 IULA World Wide Declaration of Local Self-Government. Adopted by the IULA Council, Toronto, June 1993. Available at: http://www.bunken.nga.gr.jp/siryousitu/eturansitu/charter/iula_decl_txt.html

13 UN-Habitat. UN-Habitat Guidelines on Decentralisation and Strengthening of Local Self-government, 2007 , p. 4. 
Government regarding the relationships between local authorities and citizens and participatory democracy, in Nairobi.

Encouragement of the decentralization process has outstanding importance in activity of the Council of Europe aimed at protection of the fundamental values of local democracy, which is naturally linked with the strengthening of forms of regional governance. In this area, European Charter of Regional Self-Government ${ }^{14}$ was drafted in. The Regional Charter defined at regional, and subregional level the fundamental values, but it did not receive adequate support from Member States and therefore its provisions are not binding. The so-called 'Helsinki principles' were then adopted in 2002. ${ }^{15}$ The Congress of Council of Europe approved the European Charter for Regional Democracy in 2008, on the basic values of the dominant regional democracy, which served as the basis of the Regional Framework of Reference for Democracy, adopted in 2009. The Framework arranges the principles of the regional organizational structures, their powers and resources. It defines their role within the state organization system, and their relationship to other authorities, as well as to citizen.

\subsection{Europeanization}

The process of decentralization, the transfer of specified tasks from the central government level to the lower level bodies, and the regional policy of the European Community and later of the European Union are in a close relationship. The regionalization process, strengthening the sub-national government structures, determining the framework of regional policy, and strong expansion of development funds have resulted in strengthening of regional territorial units as a kind of attempt to modernize the political system in the 1990 s. $^{16}$

Harmonization of EU law, as well as regional and cohesion policy implementation at local level have resulted in Europeanization of municipalities in the European integration process. Local selfgovernments have become part of the EU's multi-level system of government in the sense that local governments can influence the shaping of EU policies. Naturally the intensity of this process varies from state to state.

As a result of the decentralization process in Europe, the role of local self-government has changed significantly in the exercise of public power. As an assessment of European decentralization processes it is worth recalling the review of Committee (2013) that summarizes the role of local and regional authorities in EU policies. The Committee expressed its confidence that "... the effective decentralization of subsidiarity, proportionality and multilevel governance should rest on the principles," and that "the principle of subsidiarity is a political-legal crucial driving force of decentralization".

Although a single definition of Europeanization has not been established, its terminology commonly refers to the impact of European integration as the process of creating the EU's polity and the corresponding adaptation of activities and institutions within the Member States. Europeanization

14 Draft European Charter of Regional Self-Government. Available at: http://groups.csail.mit.edu/mac/users/rauch/misc/ regions/charter_self_government.html

15 Helsinki Ministerial Conference : Declaration (2002) 19 December 2008. Available at: https://wcd.coe.int/ViewDoc. jsp?p=\&id=1390053\&Site=DG1-CDLR\&BackColorInternet=B9BDEE\&BackColorIntranet=FFCD4F\&BackColorLog ged=FFC679\&direct=true

16 SOÓS, E.: A regionalizmus hatása az állami szuverenitásra. In: A 21. század eleji államiság kérdőjelei. (szerk.: Hervainé Szabó Gyöngyvér). Székesfehérvár: Kodolányi János Főiskola, 2015, p. 261-276. 
encompasses a range of different meanings within the academic literature. The most common usage includes processes such as changes in policies, practice and preferences within cities; bottom-up mobilisation, meaning the transfer of innovative urban practices to the supranational arena; horizontal processes of Europeanization for local authorities, which involve cooperation and the exchange of best practice and innovations through transnational networks; and organisational adaptation within the administrative structures of local authorities. ${ }^{17}$

The public administration systems of the Member States of European Union do not fall within the scope of the EU law, nevertheless, it should be analysed to what extent are these processes influenced by Europeanization progress and what other factors may influence these. The European Union in general considers the structure and functioning of public administration as a national internal affair. Nevertheless, public administrations of the Member States undergo a strong Europeanization and convergence process, since the implementation of European public policies depends mainly on the performance of national administrations, including local self-governments.

The impact of globalization itself influences the form and content of government. The deepening of European integration can be interpreted as a kind of response to this trend. Multilevel governance could result in lesser significance of government at national level and higher importance for the regional and local level. As a consequence of this process, national sovereignty issues can be arising. Currently, European integration and economic globalization have a powerful influence on the functions of local government and their democratic legitimacy.

\section{$3 \quad$ RIGHT AND ABILITY TO SELF-GOVERNMENT AND EUROPEAN REGIMES}

\subsection{The scope of the European Charter of Local Self-Government}

Council of Europe's aim is not to harmonize the various national laws through the adoption of common rules, but rather it lays down and specifies the fundamental principles and values, and promotes their adoption both in law and in practice. The Council of Europe is one of the most important defenders of human rights and of the institutions of democracy in the world. The activity of the Council has significant importance in the field of local democracy and local self-governance.

The basic document of local self-government's core values is the Charter of Local Self-Government which was adopted under the auspices of the Congress and was opened for signature on 15 October 1985. At present, all Member States are parties to the Charter. The Charter is the first binding international convention to reach a minimum level of legal coherence in Europe and to ensure rights for local communities and their elected local self-governing bodies.

In the focus of the Charter is the right and ability of self-governance to regulate and manage a substantial share of public affairs under their own responsibility and in the interests of the local population within the limits of the law. ${ }^{18}$ The core values of the local democracy like decentralization and subsidiarity are also in the scope of the Charter.

17 GUDERJAN, M.: Local Government and European integration - beyond Europeanisation? Political Perspectives 2012, vol. 6 (1), p. 107. Available at: http://www.politicalperspectives.org.uk/wp-content/uploads/PP_final-article6_Europeanisation-or-integration-of-local-government1.pdf

18 European Charter of Local Self-Government, Art. 3. par. 1. 


\subsection{Systematization of local self-government regimes}

As regards the practice, in this subsection the systematization of local self-government regimes can be examined.

Analysis of the European local self-government models cannot be uprooted from the sociohistorical embedded circumstances. The standardization could be based on special constitutional rules for local authorities, the position among the state organizations, the definition of tasks and responsibilities, as well as the internal structure of local governments. ${ }^{19}$

István Hoffman distinguished two classic models in pursuance of the interpretation of local self-government - following the arrangement of M. Tamás Horvath - on one hand the local selfgovernment and local administration. In addition, a third one, the so-called interactive model was also proposed by them. The interactive model includes the social relationship between local governments and local citizens.

On the basis of the examination of the constitutional position of local government, the British model and the United States model based on ultra vires principle can be distinguished. The ultra vires principle of a single administration was introduced since the 1990s in several states outside the Anglo-Saxon legal culture as well - Ukraine, Moldova, Armenia, Georgia, etc. The other large group of countries is based on general clause, general competences. These states represent differentiated responsibilities and powers in the field of local public affairs. Subgroups can be formed within this groups, where strong state control and influence prevails or the broad legal protection of selfgovernment is guaranteed by the central government. Examples of the former subgroup are France and Italy, as well as Romania and Russia. The latter one includes the Federal Republic of Germany, Poland and Czech Republic. ${ }^{20}$

In determining models of local self-governments, another distinguishing - into a monistic and a dualistic model - is also possible.

The monistic management model is based on the uniformity of the tasks carried out by local governments. In the dualistic model, in contrast, the municipal tasks and administrative tasks delegated by the State are separated. ${ }^{21}$

These models more or less exist either in a pure form, or overlapping coincidences can occur.

\section{NEW THEORETICAL APPROACH IN THE UNITED KINGDOM AND REGIONAL REFORM MEASURES IN FRANCE}

\subsection{The Big Society concept}

In the United Kingdom, the Big Society concept is in the forefront of the government policy. The focus of the concept is on local communities and is designed to provide them stronger powers and

\footnotetext{
19 See for further details: Hoffman, I.: Gondolatok a 21. századi önkormányzati jog fontosabb intézményeiről és modelljeiről. A nyugati demokráciák és Magyarország szabályozásainak, valamint azok változásainak tükrében. Budapest: Eötvös Kiadó, Eötvös Loránd Tudományegyetem, 2015.

20 Ibid., p. 78-95.

21 Ibid.
} 
more opportunities, as well as to create a new generation of community organizations, charities which are able to take part in supplying public service tasks.

There is a radical devolution of powers, which is directed from the central government towards local communities. This devolution process is accompanied by greater economic autonomy for local governments, as well as by enforcement of the principle of general authorization. ${ }^{22}$ In accordance with these efforts a Bill has been submitted in 2011, which resulted in substantial changes in the functions of local government and in greater freedom for local authorities and communities. The Local Government Act of 2011 includes a provision on general power of local government, the community, to bring any infringement to the courts, and the possibility of obtaining community assets. In sum, the ultra vires system has been replaced by a limited general clause model. New rules were also introduced: a referendum on the local tax, when excessive taxes are imposed by the local government, as well as new regulation of referenda held in other cases. A new general empowerment clause has been fixed: the local government can do anything what an individual can do, in general. ${ }^{23}$

\subsection{The French regional reforms}

The central public power has been dominant in the French public sector in which centralization has significant effects, while the administrative decentralization prevails since the $19^{\text {th }}$ century. Territorial organization of the French administrative system currently includes all forms of decentralized and de-concentrated administrative and territorial bodies. The municipalities are based on the principle of general competence in the field of local governance, which demonstrates local interests, with wide administrative powers.

The essential feature in France is the association system of local authorities. Now, the aim is to reduce the number of associations in order to foster efficiency.

Nowadays decisive reform processes have taken place in the French local government system. ${ }^{24}$ The local government system is basically influenced by the Act of 2015 on territorial subdivisions which redefined the local and regional authorities' powers and reshaped the French regional system. Substantial measure of the Act was to reduce the number of regions - from 22 to 13 - as of 1 January 2016. The Act aims to support regional level governance, and to strengthen the economic decision-making skills and capacities that are not within the competence of the state. The new regional competences will include the economic development and business promotion, regional planning, organizing transport, training, employment and public employment. In addition, the culture, sports and tourism will be shared competencies with the regions. The legal changes will fully come into force by $2017 .^{25}$

\footnotetext{
Building the Big Society.

Localism Bill 2010-11, Localism Act 2011, 15th November 2011.

24 See for further details: BALÁZS, I.: A francia helyi önkormányzati rendszer átalakulása napjainkban. Állam- és Jogtudomány LVII. évfolyam 2016. 2. Szám, p.16-39.

25 France Approves a Territorial Reform. Available at: http://www.regionsunies-fogar.org/en/media-files/107-france-approves-a-territorial-reform
} 


\section{CONCLUSION}

After World War II, in the Western European countries first decentralization efforts in the field of local governments appeared, while, on the other hand, the New Public Management-induced tendencies appeared as well. Summarizing the dominant prevailing tendencies in the field of local self-government, we can conclude that decentralization, requirement of subsidiarity and the Europeanization of municipalities cannot be clearly separated. Since the local self-government units are - inter alia - the executive bodies of the European common policies, a kind of Europeanization process can be recognized. As result, the role of local governments has become stronger.

Finally, we can conclude that the European Charter of Local Self-Government, as an internationally binding convention of the Council of Europe, has a general impact on the local self-government system, while on its basis different models can be created. Secondly, the field of local self-governance is not a part of EU legal agenda, but a lot of common features can be identified among EU Member States.

\section{Bibliography:}

BALÁZS, I.: A francia helyi önkormányzati rendszer átalakulása napjainkban. Állam- és Jogtudomány LVII. évfolyam 2016. 2. Szám, p. 16-39.

Building the Big Society. https://www.gov.uk/government/uploads/system/uploads/attachment_data/file/78979/ building-big-society_0.pdf

Decentralization: A Sampling of Definitions (Working paper prepared in connection with the Joint UNDP-Government of Germany evaluation of the UNDP role in decentralization and local governance) October 1999. Available at: http://web.undp.org/evaluation/evaluations/documents/decentralization_working_report.PDF

Draft European Charter of Regional Self-Government. Available at: http://groups.csail.mit.edu/mac/users/rauch/ misc/regions/charter_self_government.html

GRINDLE, M. S.: Going Local. Decentralization, Democratization, and the Promise of Good Governance. Princeton and Oxford: Princeton University Press, 2007.

France Approves a Territorial Reform. Available at: http://www.regionsunies-fogar.org/en/media-files/107-franceapproves-a-territorial-reform

GUDERJAN, M.: Local Government and European integration - beyond Europeanisation? Political Perspectives 2012, vol. 6 (1), p. 105-128. Available at: http://www.politicalperspectives.org.uk/wp-content/uploads/PP_finalarticle6_Europeanisation-or-integration-of-local-government1.pdf

HOFFMAN, I.: Gondolatok a 21. századi önkormányzati jog fontosabb intézményeiről és modelljeiről. A nyugati demokráciák és Magyarország szabályozásainak, valamint azok változásainak tükrében. Budapest: Eötvös Kiadó, Eötvös Loránd Tudományegyetem, 2015.

IULA World Wide Declaration of Local Self-Government. Adopted by the IULA Council, Toronto, June 1993. Available at: http://www.bunken.nga.gr.jp/siryousitu/eturansitu/charter/iula_decl_txt.html

Helsinki Ministerial Conference : Declaration (2002) 19 December 2008. Available at: https://wcd.coe.int/ViewDoc. jsp?p=\&id=1390053\&Site=DG1-CDLR\&BackColorInternet=B9BDEE\&BackColorIntranet=FFCD4F\&BackCol orLogged $=$ FFC679\&direct $=$ true

KELSEN, H.: Az államélet alapvonalai. Prudentia Iuris 7. Miskolc, 1997.

KOVÁCS, L.: Helyi önkormányzatok hálózatainak szerepe a globális kormányzásban. In: Tér és Társadalom, 24. évf. 2010/1.

PAGE, E. C.: Localism and Centralism in Europe. The Political and Legal Bases of Local Self-Government. Oxford: Oxford University Press, 1991. 
PÁLNÉ, K. I.: A helyi-területi önkormányzati rendszerek. In: Összehasonlító alkotmányjog (szerk. Tóth Judit - Legény Krisztián). Budapest: Complex Kiadó, 2006, p. 281-327.

PÉTERI, G.: Decentralization in Eastern Europe: Grab the Moment! Available at: http://www.kozjavak.hu/en/decentralization-eastern-europe-grab-moment

RIBOT, J. C.: Democratic Decentralization of Natural Resources: Institutionalizing Popular Participation.. Washington DC: World Resources Institute, 2002. Available at: http://pdf.wri.org/ddnr_full_revised.pdf 1-2.

SAITO, F. (ed.): Foundations for Local Governance. Decentralization in ComparativePerspective. Heidelberg: Physica-Verlag, 2008.

SOÓS, E.: A regionalizmus hatása az állami szuverenitásra. In: A 21. század eleji államiság kérdőjelei. (szerk.: Hervainé Szabó Gyöngyvér). Székesfehérvár: Kodolányi János Főiskola, 2015, p. 261-276.

United Cities and Local Governments (UCLG). Decentralisation and local democracy in the world. First UCLG World Report. Barcelona: UCLG, 2008.

UN-Habitat. UN-Habitat Guidelines on Decentralisation and Strengthening of Local Self-government, 2007. http:// www.cities-localgovernments.org/committees/dal/Upload/news/ladsguidelines.pdf

WAGANA, D. M. - IRAVO, Mike A. - NZULWA, Joyce D.: Analysis of the Relationship Between Devolved Governance, Political Decentralization, and Service Delivery: A Critical Review of Literature. In: European Scientific Journal, vol. 11, November 2015, No. 31, ISSN: 1857 - 7881 (Print) e - ISSN 1857- 7431 457-472.

\section{Contact information:}

dr. Judit Siket

Siket.Judit@juris.u-szeged.hu

University of Szeged, Faculty of Law and Political Sciences

54. Tisza Lajos bld.

6720 Szeged

Hungary 